\title{
Students' Confidence in Expressing Opinions at a Senior High School in Pademawu
}

\author{
Andik Matulessy ${ }^{1, *}$, Uslah Rosidhatul Hikmah² \\ 1, 217 Agustus 1945 University of Surabaya, Indonesia \\ *Corresponding Email: andikmatulessy@untag-sby.ac.id
}

\begin{abstract}
This research is motivated by the existence of students who experience low self-confidence in expressing opinions during discussion forums in class so that it has an impact on their lessons at school. The purpose of this study was to determine the students' confidence in expressing their opinions at SMA Negeri 1 Pademawu (a senior high school). This study uses a qualitative approach. Sources of data were obtained by interviews and observations. The type of interview used is unstructured interview while the type of observation used is the participant and non-participant observation. The research subjects are students of class XI SMA Negeri 1 Pademawu. The results of this study indicate that the factors that affect students' confidence in expressing opinions are internal from innate or genes because of one parent who has the same nature so that it can be passed on to their children. And also to increase students' confidence in expressing opinions, namely the cognitive restructuring method to change negative thinking patterns into positive ones.
\end{abstract}

Keywords: Confident, Express Your Opinion, Teenagers

\section{INTRODUCTION}

The development of early adolescence can be seen since they were 12 years old, in a very rapid development phase, it is clear that there are changes that include physical, intellectual, social, moral, language, emotions and feelings, interests, motivations, attitudes, personality, talents, and creativity. Where in each of these aspects create new combinations or relationships which then form physical and psychological specialities that differ from one human to another. (Yudi, 2011) Individual beliefs about themselves, both teenagers and adults, arise because they have self-confidence. Someone who has the confidence to do anything with the belief that it will succeed, if it fails, someone does not necessarily despair but still has the spirit to try again. Everyone's selfconfidence is an attitude or feeling of confidence in their abilities. So that the individual concerned is not too anxious in every action he can freely do the things he likes and is responsible for all actions that are carried out warmly and politely in interacting with other people. Self-confidence is an important part of a person's personality development as a determinant of a person's attitude and behaviour as well as a determinant of their success in learning.

Lauster defines self-confidence as derived from life experiences. Self-confidence is one aspect of personality in the form of belief in one's own abilities so that they are not influenced by others and can act according to their will, happy, optimistic, tolerant enough, and responsible (Hendra, 2016).

Self-confidence is one of the most important aspects of a person's personality. Without self-confidence will cause a lot of problems in a person. Self-confidence is the most valuable attribute in a person in social life. Due to self-confidence, a person can actualize all his potential. Self-confidence is important for every individual to have. Individual and group self-confidence (Gufron \& Rini, 2017).

Self-confidence is formed through the learning process by interacting with the surrounding environment, various factors that affect students' self-confidence, namely internal factors and external factors. Internal factors are factors that come from within the individual, which includes personality, intelligence, physical conditions and others. While external factors are factors that come from outside the individual, which includes parenting patterns, school environment, and the surrounding community.

Lack of self-confidence in students first arises because of fear, anxiety, worry, uncertainty accompanied by chest palpitations, and body shaking which is psychological or psychological problems in children caused by external stimuli. The lack of confidence faced by students is caused by feelings of anxiety and restlessness and other feelings that follow, such as laziness, impatience, difficulty, or low self-esteem, this is 
what makes individuals doubt their abilities and themselves.

The problem of self-confidence that has emerged the most recently among teenagers is always related to education and teaching, especially in classroom learning related to the courage to express opinions in discussion forums. This will be an obstacle for students to achieve success in learning. The involvement of students who lack interaction and lack good communication with fellow students can have a bad impact on their motivation in learning achievement.

The ability to express opinions is the ability to convey ideas or thoughts orally logically, without imposing their own will and using good language. The ability to express opinions mastered by students is expected to help obtain optimal learning outcomes. If students cannot express opinions, it is feared that students will experience various disorders and obstacles in achieving learning success. This can be considered as an obstacle for students to succeed in learning because the ability to express opinions will show their ability to think (Diah Ayu P, 2015).

According to Ahmadi, expressing an opinion is a result of thought in which there is a relationship between one response to another expressed in a sentence. However, speaking in public often creates a sense of fear for some people, including students at school. This fear is usually shown through words in the form of complaints and shows a pessimistic attitude. In addition, another characteristic is that they are less courageous in expressing their opinions, ideas and ideas. Another thing is shown by being afraid when asked to ask questions by the teacher. Feeling nervous, restless, and breaking out in a cold sweat when asked by the teacher to answer questions. These reactions arise from the assumption that students are afraid that their opinions may be wrong and will be scolded by the teacher for their mistakes.

It is not always easy for students to express their opinions clearly so that they are easily understood by others. Especially if the opinion is rather complex because it involves a complicated problem.

To be able to express opinions clearly so that they are easy to understand, students need to learn and train themselves to use the right words and arrange them into good sentences. Besides that, students must also be able to express the idea in a logical order. A good exercise to develop the ability to express opinions can be done by learning to compose, practice speeches, and have discussions. Such exercises are best done from a young age. In this regard, in the past, students from elementary school to senior high school were given intensive lessons and training in coral composition. Thus they are forced to organize their ideas and put them in a language that can be understood by others.

Students who lack confidence in expressing opinions will not always be like that. Confidence in expressing opinions can be increased. Students can learn to be more confident. But you have to work on it in the right way, and you have to practice it. Students must put in the effort, and if the effort is well directed, it can make a big improvement in self-confidence, especially in expressing opinions. (Kenneth Hambly, 1989). If there is a motivation for students to change their behaviour to become confident individuals. Motivation can generate and encourage behaviour, provide direction or purpose for behaviour, provide opportunities for the same behaviour and lead to certain behavioural choices.

Based on observations made by researchers at SMA Negeri 1 Pademawu by interviewing BK teachers as well as looking directly at the teaching and learning process, there are students in class XI IPA 1 who have low confidence in expressing opinions, ideas and ideas. Those who lack confidence, stuttered speech, slightly pale face, sweaty body, embarrassed to look at their friends and trembled.

\section{METHOD}

In this study, the research approach used is qualitative research. Qualitative research is research that intends to understand phenomena about what is experienced by research subjects such as behaviour, perceptions, motivations, actions, and others holistically, and using descriptions in the form of words and language in a special context that is natural and natural. using various scientific methods. (Lexy j Molong, 2012)

\section{RESULTS AND DISCUSSION}

\subsection{Self-confident}

Self-confidence can be interpreted as a person's belief to be able to behave following expectations or desires. If a person does not have self-confidence, many problems will arise, because self-confidence is an aspect of a person's personality that functions to actualize his potential. Self-confidence is an aspect of personality that is formed through the interaction of individuals with their environment. (Hendra, 2016)

According to Willis, self-confidence is the belief that a person can cope with a problem with the best situation and can provide something pleasant for others. So selfconfidence is very important for people, especially 
among teenagers to express themselves in their social environment.

\subsection{Types of Confidence}

Confidence is confidence in one's abilities and selfassessment in performing a task and choosing an effective approach. This includes confidence in his ability to deal with an increasingly challenging environment and trust in his decisions or opinions. There are two types of self-confidence, namely external and internal. More details can be seen in the following description.

\section{a. Confidence Born}

Self-confidence is born to make the individual must be able to give to the outside world that he believes in himself, namely starting to develop skills in certain fields. These skills include the following.

1) Communication

2) Firmness

3) Self Appearance

4) Feeling Control

b. Inner self-confidence
1) Self Love
2) Self Understanding
3) Positive thinking
4) Clear goals

\subsection{Factors Affecting Confidence}

In life, it is very necessary to believe in yourself to achieve success. The key to gaining confidence is understanding yourself. Individuals must believe in their abilities and potential. Don't let pessimism and anxiety always haunt your feelings. Self-confidence can be influenced by several factors that can be classified into two, namely internal factors and external factors. More details can be seen in the following description:

\section{a. Internal factors}

This internal factor consists of several important things in it. These matters include the following.

- Self Concept

- Self-Esteem

- Physical Condition

- Live

\section{b. External Factors}

This external factor also consists of several important things in it. These include the following:
1) Education

2) Job

3) Environment

\subsection{Characteristics of Individuals who have Confident and Unconfident}

Self-confidence is an attitude or belief that is in oneself. Confidence is not about compensating a weakness for an advantage. However, how the individual can accept himself as he is, be able to understand what he is like and in the end will believe that he can do things well. The characteristics of people or individuals who have self-confidence, including the following:

- Confidence in one's abilities, which is a belief in oneself in all phenomena that occur related to the individual's ability to evaluate and overcome the phenomena that occur.

- Act independently in making decisions. That is, being able to act in making decisions about oneself that are carried out independently or without the involvement of others and being able to believe in the actions taken.

- Have a positive sense of yourself. That is the existence of a good assessment from within oneself, both from the views and actions taken that create a positive sense of oneself and their future

- Dare to express opinions. The existence of an attitude to be able to express something in oneself that wants to be expressed to others without any coercion or feeling that can hinder the disclosure.

- Be calm in doing something

The opinion that states that people who are not confident have the following characteristics:

- Keep a fear or worry about rejection

- Difficult to accept in reality

- Pessimistic or easy to judge everything from the negative side

- Not daring to express ideas

- Tend to just watch and wait for opportunities

\subsubsection{Opinions}

Opinions are to put forward ideas. How to express opinions well means expressing opinions in a reasonable context and conveying them using logical ideas or thoughts orally without forcing their own will and using good language. This is evident in the expression of the language used must be good, precise, and thorough (Jos danil, 1897). Expressing opinions analytically means being able to express opinions systematically and 
regularly. To be able to express opinions analytically is necessary to deepen the problem, it is necessary to have the habit of expressing opinions directly and not convoluted, but each problem is analyzed in detail one by one. Expressing an opinion logically means expressing an opinion that makes sense. Expressing opinions is the right of all individuals in interacting and communicating with others, including students. As Powell said that communication consists of 5 levels, where the third level is expressing opinions. By expressing an opinion, someone is said to have done one level of communication.

\subsubsection{Various Opinions}

Expressing an opinion is a person's need to be able to express his feelings and thoughts to others. Expressing an opinion is a form of communication made by one person to another. There are various types of opinion, Sastropoetro Santoso states that the various opinions in everyday life are as follows (Santoso, 1990):

- Individual/individual opinion is an opinion expressed by someone openly in front of other people who are in a group, both formal and informal.

- Personal opinion is an opinion expressed by a person to another person who has a close relationship with him or who he believes.

- Group opinion is an opinion expressed by a group of people through their spokesperson (group leader or other people).

- A consensus opinion is an opinion that results from an agreement among group members.

- Coalition opinion is an opinion that results from a combination,

- Gather spontaneously and discuss controversial issues

\subsubsection{Aspects of Expressing Opinions}

Courage to express opinions is indeed not something easy, because to be able to express opinions that are understood and understood by others, one must be able to connect the various ideas he has to build a good and interesting understanding and delivery. Rina Sugiyati revealed that the aspects that must be considered in expressing opinions freely and responsibly are:

- His opinion must be accompanied by strong and reasonable arguments so that it is not just any opinion.

- Opinions should represent the interests of many people, to provide benefits for the common life.

- His opinion is expressed within the framework of applicable regulations so that it does not violate the law.
- $\quad$ People who think should be open to feedback, to create good social communication.

- Expression of opinion should be based on the desire to develop the values of justice, democracy and welfare.

\section{RESULTS}

In this study, the researcher examined students' selfconfidence in expressing opinions in class XI science at SMA Negeri 1 Pademawu. Based on the results of interviews, observations and analyze the questionnaire. Researchers found findings related to students' confidence in expressing opinions in class XI IPA 1 SMA Negeri 1 Pademawu that the results of interviews with several informants, observations and documentation showed that the level of student confidence was quite good. Not only that, but the researchers also analyzed the Who Am I questionnaire with the following results:

- Questionnaire analysis of Who Am I in class XI IPA 1, the level of students' confidence in expressing their opinions shows sufficient results. Meanwhile, students who have low selfconfidence in expressing opinions are shown by 1 student who has FR (a pseudonym) of 27 students.

- Students' confidence in expressing opinions in class XI IPA 1 is quite good, because at the time of presentation, on average, students are actively asking and giving opinions.

- Students of class XI IPA 1 have good intellectual abilities because the class is famous for its superior class so most students have a high interest in reading.

- Class XI IPA 1 students have implemented lessons that use discussion forums such as presentations and that can train their ability to express opinions.

The researcher also found a factor in the selfconfidence of FR students (a pseudonym) in expressing opinions, namely internal factors from (within). The following are internal factors that affect the confidence of FR students in expressing opinions:

- Hereditary factors or genes from both parents. FR students have self-confidence problems because of the gene from one parent who has the same nature so that it can be passed on to their children.

- Factors from themselves who have a quiet nature, factors from themselves, FR students have a quiet nature which makes it difficult to communicate with other friends. 
- The findings of researchers related to how to increase students' confidence in expressing opinions are as follows;

- Schools have implemented Scouting activities, discussion forums such as presentations, participating in extracurricular activities, namely Intra-School Organizations (OSIS), Journalism Training can increase students' confidence in expressing opinions.

- Counselling teachers have their techniques or methods to increase their confidence in expressing opinions, namely the cognitive restructuring method to change negative thinking patterns into positive ones and symbolic modelling (imitation of outstanding figures to get the desired behaviour).

- Researchers provide symbolic modelling methods/techniques to FR students to increase their confidence in expressing their opinions.

\section{REFERENCES}

[1] Jahja, Yudrik. Developmental psychology. Jakarta: Kencana, 2011.

[2] Ali, Mohammad and Mohammad Asrori. Adolescent Psychology. Jakarta: PT Bumi Aksara, 2004.

[3] Widjaja, Hendra. Dare to Be Different and Confident. Yogyakarta: Araska, 2016.

[4] Ghufron, M. Nur and Rini Risnawati S. Psychological Theories. Jogjakarta: Ar-Ruzz Media, 2017.

[5] Parera, José Daniel. Learn to Express Opinions. Jakarta: Erlangga, 1987.

[6] Prameswari, Diah Ayu, "Application of Participant Modeling Strategies to Increase Courage in Expressing Opinions to Students." Student Journal. Unesa.ac.id, 2015.

[7] Hamby, Kenneth. How to Increase Confidence. Jakarta: Arcan, 1989.

[8] Iswidharmanjaya, Derry, Gregory the Great, One day to be more Confident. Jakarta: PT Elex Media Komputindo, 2004.

[9] Joseph, Luxori. Self-confident. Jakarta: Khalifa, 2001.

[10] Sastropoetro, Santoso. Public Opinion, Public Opinion and Audience Opinion in Social Communication. Bandung: Rosdakarya Youth, 1990.

[11] Poerwadarminta, W.J.S. General Indonesian Dictionary. Third edition. Jakarta: Balai Pustaka, 2007.

[12] Yuliana, "The Relationship of Self-Concept and Ability to Express Opinions with Civics Learning
Achievement in Grade X Students". Thesis, University of Lampung, Bandar Lampung, 2016.

[13] Moleong, Lexy J. Qualitative Research Methods Revised Edition (Bandung: Rosdakarya Youth, 2012. 